\title{
Operação do SEPG na Motorola Brasil
}

\author{
Jose Mário de Souza Lima Filho- Jose.Lima@motorola.com \\ Ana Luísa Andrade Florencio- Ana.Florencio@motorola.com \\ Márcia Cristina Carvalho Costa - Marcia.Costa@motorola.com \\ Cibele Brunetto - Cibele.Brunetto@motorola.com \\ Motorola Industrial Ltda. \\ Rodovia SP 340, km 128,7 - Tanquinho \\ Jaguariúna - SP - Brasil \\ CEP 13820-000
}

\section{Resumo}

Este artigo descreve a experiência da Motorola Brasil na implantação e gerenciamento de seu SEPG (Software Engineering Process Group) - desde sua criação até a certificação CMM [1] nível 3, obtida em Novembro de 2001. São apresentados estrutura, atividades, responsabilidades, métricas de controle, resultados e lições aprendidas.

\section{Palavras Chave}

CMM, Software, SEPG, Qualidade e Processo.

\begin{abstract}
This article describes Motorola Brazil's experience in deploying and managing the SEPG - Software Engineering Process Group - from creation to CMM [Paulk94] level 3 certification, in November 2001. It presents activities, structure, responsibilities, verifications and measurements. Also results achieved and lessons learned.
\end{abstract}

\section{Key-words}

CMM, Software, SEPG, Quality and Process.

\section{Introdução}

\subsection{A Motorola no Brasil}

A Motorola Industrial Ltda. opera no Brasil na fabricação de equipamentos para comunicações sem fio, nas áreas de telefones celulares, rádios, infra-estrutura de comunicação sem fio, comunicações de banda larga e iDEN (sistemas integrados celulares, rádio e pagers).

Também possui equipes de desenvolvimento trabalhando com hardware e software, nas áreas de telefones celulares, infra-estrutura e desenvolvimento de projetos de semicondutores. Estas equipes estão localizadas no campus integrado de Jaguariúna, SP, e têm intensos relacionamentos com Universidades e Centros de Pesquisa no Brasil e no mundo.

\subsection{O Centro de Desenvolvimento de Software - Brazil Design Center}

O BDC (Brazil Design Center) foi criado para servir de suporte às necessidades da Motorola América Latina na engenharia do software de telefones celulares, permitindo a criação e a adaptação de funcionalidades às características específicas da região.

Os centros de desenvolvimento de software da Motorola são avaliados em função de seu nível de maturidade CMM (Capability Maturity Model) [1] e têm como objetivo primário a obtenção do nível 5 no prazo de 5 anos (1 nível por ano). O BDC foi criado no final de 1999, 
efetivamente iniciando seu primeiro projeto em janeiro de 2000 , em conjunto com a implantação da primeira etapa do modelo CMM, visando a certificação nível 3.

A estratégia aplicada foi a adoção e a adaptação do processo global de desenvolvimento de software da engenharia de celulares da Motorola, criando um suplemento de processos adaptados à realidade dos projetos regionais, conforme figura 1 .

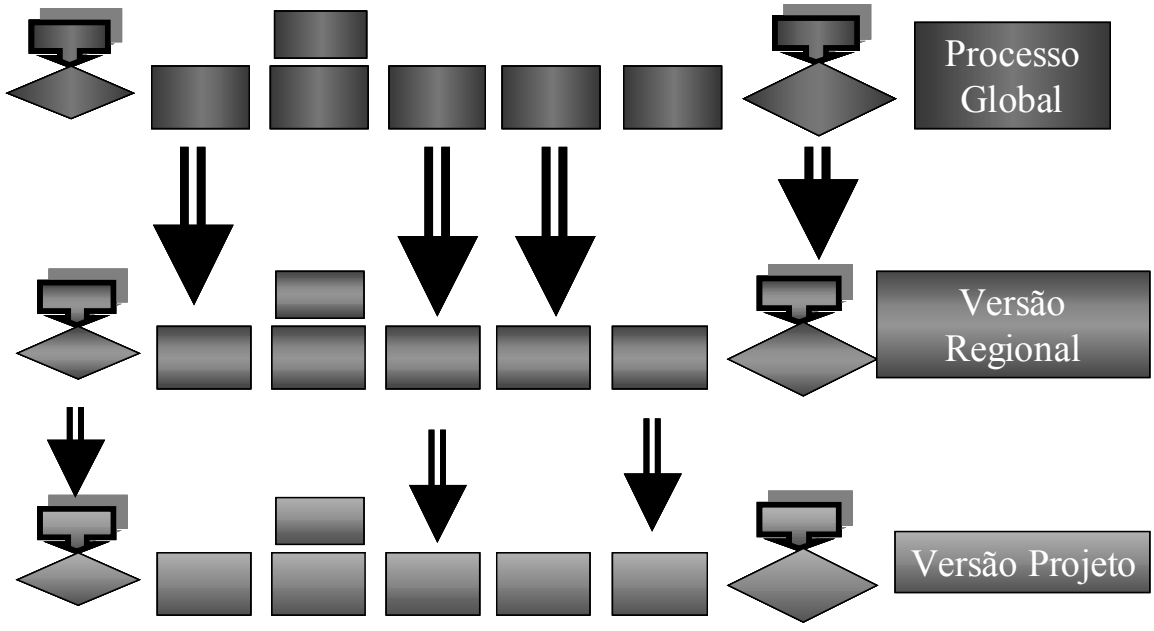

\section{Figura 1 - Estratégia de adaptação de processo de desenvolvimento de software}

Foram realizadas quatro avaliações (assessments) CMM, uma a cada seis meses, para avaliar a evolução da maturidade da organização e prover dados para melhorias do processo e correção de rumos.

\section{Implantação do SEPG}

Uma das primeiras providências no BDC foi a criação de um grupo responsável pelo gerenciamento do processo, o SEPG (Software Engineering Process Group) com representantes das várias áreas afetadas e que poderiam colaborar na adaptação do processo às necessidades da região.

O SEPG é o modelo mais comum de implantação da Habilidade 1 da KPA (Key Process Area) OPF (Organization Process Focus) do CMM [1].

O SEPG foi composto pelos chamados KPA Champions - especialistas responsáveis pelo desenvolvimento do processo relativo a sua KPA - e pelos gerentes de desenvolvimento de SW.

Os membros do SEPG são desenvolvedores de software e têm o seu comprometimento assegurado através de autorização do gerente responsável, que aloca no mínimo 2 horas semanais para o trabalho com processo.

Nesta fase foram designados um KPA Champion e um substituto para cada área chave de processo do nível 2 e 3 (total de 13), perfazendo uma equipe de 15 pessoas (algumas pessoas participaram de mais de uma KPA).

Além disso existe o SEPG Chairperson, responsável pelas atividades de organização atas, métricas, agenda e coordenação - das reuniões.

O SEPG também é o fórum onde os KPA Champions apresentam a cada três meses a situação de sua KPA para o Senior Manager (de acordo com o modelo CMM - Verificações das KPAs - as atividades das KPAs são revistas periodicamente com a gerência sênior [1]). 


\section{Atividades}

As principais atividades do SEPG foram o gerenciamento de mudanças de processo, atuando como Comitê de Controle de Mudanças (CCB - Change Control Board), e o acompanhamento de problemas relativos à implantação do processo, atuando como comitê diretivo. Se levarmos em conta o modelo CMM, são Atividades da KPA OPD (Organizational Process Definition) e Habilidades e Compromissos da KPA OPF (Organizational Process Focus).

\subsection{Gerenciamento de mudanças de processo - Change Control Board (CCB)}

O SEPG atua em reuniões quinzenais como o CCB para determinar as mudanças de processo, analisando impacto, aplicabilidade e prioridade. Também atua alocando recursos para a implementação das alterações. Normalmente o KPA Champion é o responsável pela implementação da mudança, auxiliado por uma equipe de suporte designada pelo SEPG, caso seja necessário.

Qualquer pessoa no departamento pode abrir uma solicitação de alteração de processo, chamada PCR (Process Change Request). O ciclo de vida de uma PCR está exemplificado na figura 2.

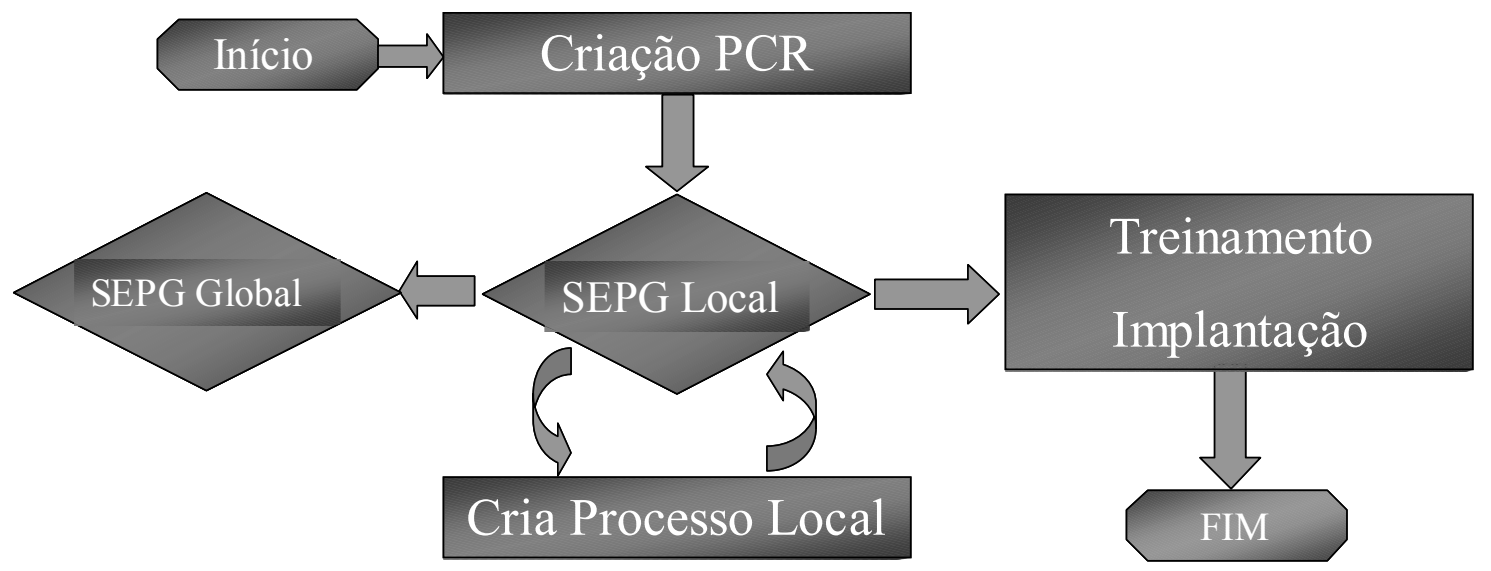

Figura 2 - Exemplo de ciclo de vida de PCR

As PCR são analisadas para verificarmos se podem ser implementadas localmente ou são referentes ao processo global da Motorola. Caso afetem o processo global da Motorola, elas são encaminhadas para o SEPG global, que se encarregará de analisá-las e definir aplicabilidade, prioridade e recursos para desenvolvimento e implantação.

No caso de implantação local, o KPA Champion afetado é encarregado de analisá-la e emitir um parecer sobre a viabilidade e impacto, principalmente levando em conta melhorias em qualidade, produtividade e ciclo de vida.

Baseado neste parecer o SEPG decide ou não pelo desenvolvimento do novo processo ou implementação de melhoria proposta pela PCR. Em caso positivo é alocada uma equipe para realizar a criação, documentação e teste do novo processo, que depois de aprovado será oficializado para uso geral, acompanhado de treinamento e implantação em toda a organização.

Uma PCR é considerada concluída pelo SEPG quando a documentação estiver aprovada, os usuários treinados e o processo em uso por toda a organização. 


\subsection{Gerenciamento da implantação do processo - Controle de Problemas}

A implantação do CMM é gerenciada como um projeto (OPF Atividade 2), por isso o SEPG tem reuniões quinzenais focadas no acompanhamento da implantação. Nelas o gerente do projeto apresenta o status geral e são discutidos cronograma, recursos, dependências e riscos.

Delas participam os membros do SEPG e os gerentes da organização, visando resolver alocação de recursos e problemas de interesse geral.

Para este acompanhamento existe uma ata de reuniões e uma lista de problemas, onde são definidos assunto, responsável, prazo e situação atual, conforme figura 3.

A situação de cada problema é verificada nas reuniões e um resumo anotado para histórico. A estimativa original para resolução do problema (Due Date) é mantida e caso seja necessário replanejar a nova data é anotada em Forecast Date. Desta maneira podemos comparar as estimativas iniciais contra o efetivamente realizado, permitindo melhoria na capacidade de avaliação de prazos para implantação de melhorias de processo.

Quando o problema é considerado resolvido, o campo Closed Date é preenchido e então é calculado o tempo de atraso contra a primeira estimativa (Planned $x$ Actual).

Como os recursos disponíveis são poucos, priorizamos os esforços usando um campo de Impacto (Impact). Ele tem valor Alto, Médio e Baixo. Os itens considerados de maior impacto devem ser tratados em primeiro lugar.

Latin America Engineering SEPG Issues List

\begin{tabular}{|c|c|c|c|c|c|c|c|c|c|c|}
\hline \# & Issue / Task & Status / Comments & $\begin{array}{c}\text { Originat } \\
\text { or }\end{array}$ & $\begin{array}{c}\text { Stat } \\
\text { us }\end{array}$ & $\begin{array}{c}\text { Person } \\
\text { Resp. }\end{array}$ & $\begin{array}{c}\text { Due } \\
\text { (planned) } \\
\text { Date }\end{array}$ & $\begin{array}{c}\text { Forecast } \\
\text { Date }\end{array}$ & Impact & $\begin{array}{c}\text { Closed } \\
\text { Date }\end{array}$ & $\begin{array}{c}\text { Planned } x \\
\text { Actual }\end{array}$ \\
\hline 103 & $\begin{array}{l}\text { The supplier selection procedure is } \\
\text { correctly defined for new projects but not } \\
\text { fully reflected on BR02627 - Pg. } 10 \\
\text { (item7) (SSM, Ac2) }\end{array}$ & $\begin{array}{l}\text { 14-Nov - Assigned responsible. Waiting for analysis. } \\
\text { 28-Dec - changed to VR.Open Process CR. } \\
\text { 5-Dec - document under review } \\
\text { 12-Dec - Under signature collection in eDoc's CRxxxxx }\end{array}$ & $\begin{array}{l}\text { Assessm } \\
\text { ent }\end{array}$ & 3 & VR & 05-Dec-01 & 21-Dec-01 & High & 4-Jan & (30) \\
\hline
\end{tabular}

Figura 3 - Exemplo de lista de controle de problemas

\section{Métricas}

As atividades do SEPG são monitoradas através de duas métricas: Status dos Problemas do SEPG e Status das PCR (OPF Métrica 1, OPD Métrica 1).

\subsection{Status dos Problemas do SEPG}

O objetivo desta métrica é acompanhar a situação da resolução de problemas gerais relativos ao projeto de implantação do $\mathrm{CMM}$, que necessariamente não estão relacionados a processo.

É medido o número de problemas em aberto mas dentro do prazo (on track), em atraso (behind and problem) e o atraso médio dos itens em aberto (average slippage).

Foram definidas metas para os itens críticos: número de itens em atraso (máximo de 5) e atraso médio máximo (40 dias). Estas metas foram baseadas nas médias do ano anterior e compromissadas entre a gerência e os membros do SEPG.

Os dados para esta métrica são coletados das atas das reuniões e do acompanhamento de problemas. Um gráfico exemplo é mostrado na figura 4. 
Ações são tomadas pelo SEPG visando manter as métricas dentro das metas, seja através de alocação de mais recursos ou analisando e mudando as prioridades dos maiores ofensores.

Por exemplo, um problema com atraso (slippage) muito grande - por exemplo 90 dias - afeta a métrica em geral, aumentando a média. Um esforço extra, focado em resolver o problema, é determinado visando retornar os valores do indicador aos valores desejados.

SEPG Issues Status

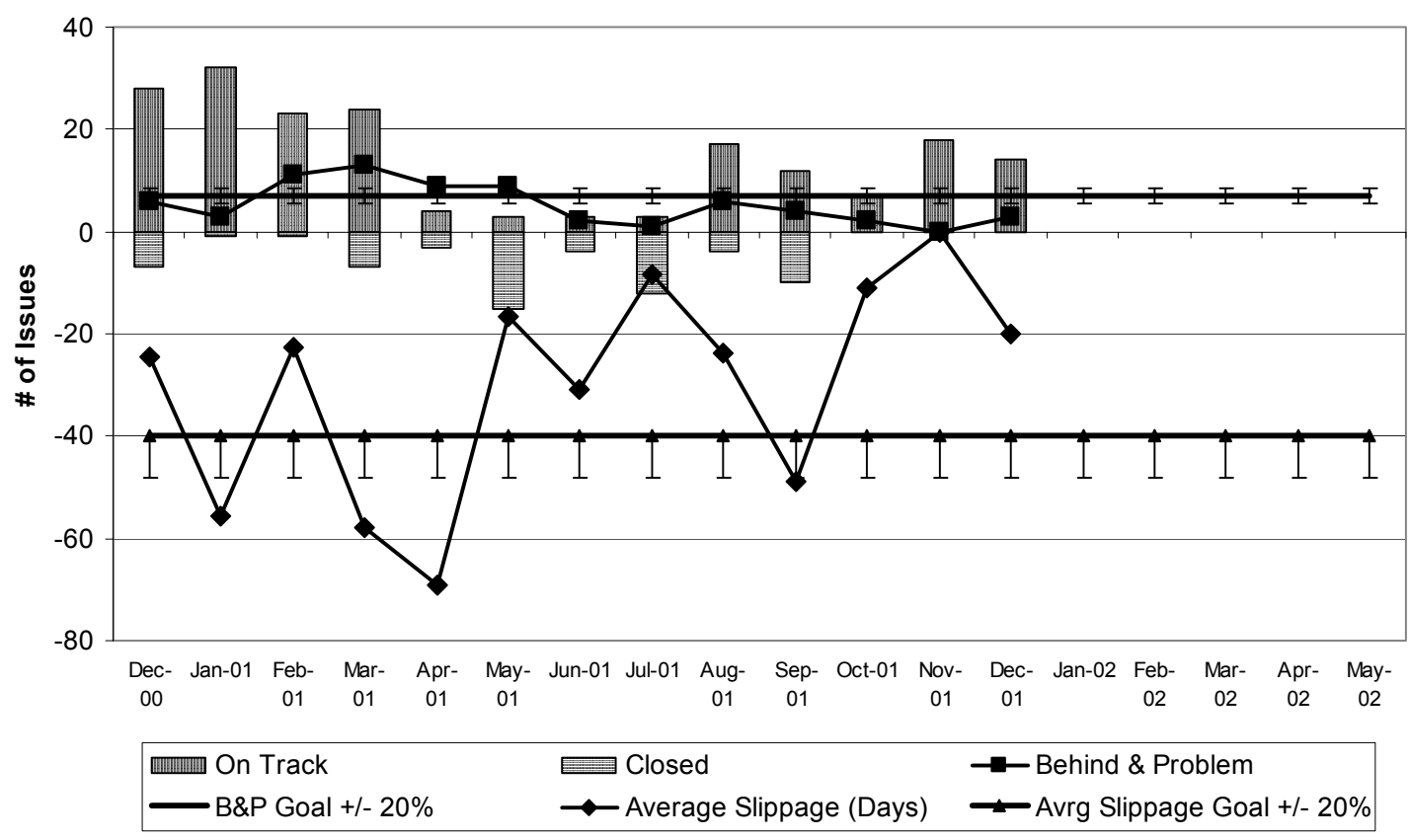

Figura 4 - Exemplo de métrica: Status dos Problemas do SEPG

\subsection{Status das PCR}

Para dar uma visão geral da situação das PCR são acompanhados os seguintes indicadores:

- Número de novas PCRs (New),

- Número de PCRs fechadas (Closed) e

- Número de PCRs em atraso, com mais de um mês de idade (Backlog).

Foi considerado crítico o número de PCRs em atraso (backlog), por isso determinada uma meta baseada no histórico do ano anterior.

Uma conclusão interessante desta métrica é que se pode ter uma idéia da capacidade da organização em resolver PCRs, como por exemplo a quantidade de PCRs por mês e o tempo médio para resolução, permitindo estimativas mais precisas.

Quando há um grande número de solicitações a tendência é o valor de atrasos crescer rapidamente devido a baixa capacidade da organização de se adaptar a flutuações de demanda. O resultado é que são necessários mutirões para verificação de PCRs, aumentandose o rigor na análise de prioridades e eliminando-se tudo o que não represente resultado significativo para a organização, permitindo o foco nas melhorias mais significativas. 
Outro evento interessante é o fluxo de PCRs após as avaliações formais, refletindo a autoanálise da organização durante o processo e a busca de correção de rumos.

O gráfico da figura 5, mostra que os meses de julho e agosto 2001 - meses nos quais a organização passou por avaliação externa - foram bastante prolíficos, com as equipes documentando os pontos que consideraram problemáticos no processo, derivados das atividades de avaliação. Importante notar que estes PCRs foram gerados pelas próprias equipes auditadas e representam a visão interna de melhorias de processo.

As não conformidades levantadas pelas equipes durante a avaliação formal também foram documentadas, mas são em quantidade menor (entre 7 e 10).

\section{Process CRs Status}

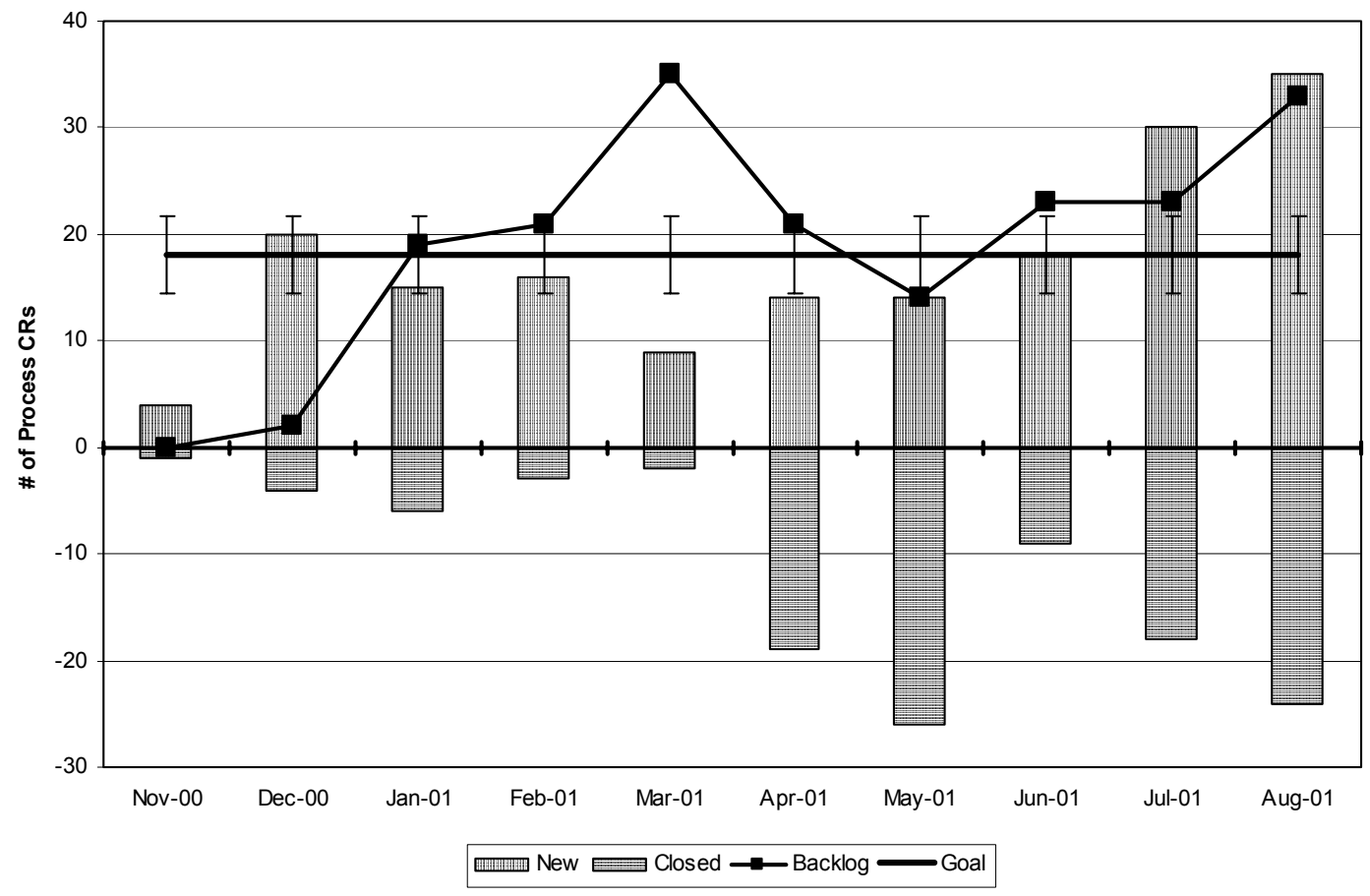

Figura 5 - Exemplo de métrica: Status das PCR

\section{Resultados}

- Certificação CMM nível 2 em dezembro de 2000, com apenas 1 ano de existência da organização e cumprindo todas as metas das áreas chaves de processo OPD e OPF.

- Certificação CMM nível 3 em novembro de 2001, com as KPA's de OPD e OPF considerados pontos fortes da organização.

- A institucionalização do processo, ou seja, o uso do processo como base para todos os projetos através de "tailorings" também foi considerada ponto forte da organização.(OPD Atividade 4)

- Foram implementadas 153 melhorias de processo no período, criando uma base sólida para a implantação dos próximos níveis CMM. 


\section{Lições aprendidas}

- O acompanhamento semanal é fundamental para que as práticas sejam efetivamente implementadas na organização.

- A participação do corpo gerencial no SEPG suporta a alocação de recursos e permite solução rápida de problemas de recursos.

- A participação dos desenvolvedores de software no SEPG como especialistas de processo gera uma carga indesejada para os projetos e o tempo de desenvolvimento de processo é mais longo do que em organizações com SEPG dedicado, mas as vantagens vêm com a rápida adoção do processo pelos times, pois ele é criado por quem efetivamente vai utilizá-lo.

- Os itens considerados críticos pela organização devem ser acompanhados por métricas específicas e as metas devem ser estabelecidas em função do histórico da organização, da disponibilidade de recursos e dos seus objetivos futuros. Métricas devem ser acompanhadas semanalmente e o SEPG deve tomar ações em tempo para correção dos desvios para que seu uso seja efetivo. Caso contrário serão apenas gráficos que não agregarão valor algum ao processo de gerenciamento.

- A implantação do CMM deve ser gerenciada como um projeto normal, ou seja, usamos os princípios de gerência de projeto do CMM para gerenciar a sua própria implantação.

\section{Referência Bibliográfica}

1. Paulk, Mark C., et al. The Capability Maturity Model - Guidelines for Improving the Software Process, Addison Wesley, 1994 